\title{
Morphometric age estimate of the last phase of accelerated uplift in the Kazdag area (Biga Peninsula, NW Turkey)
}

\author{
A. Demoulin ${ }^{\mathrm{a}, \mathrm{b}, *}, \mathrm{~T}$. Bayer Altin ${ }^{\mathrm{c}}, \mathrm{A}$. Beckers ${ }^{\mathrm{a}}$ \\ a Dept. of Physical Geography and Quaternary, University of Liège, Liège, Belgium \\ ${ }^{\mathrm{b}}$ Fund for Scientific Research - FNRS, Brussels, Belgium \\ c Dept. of Geography, Faculty of Science and Letters, Niğde University, Turkey
}

\section{A R T I C L E I N F O}

\section{Article history:}

Received 7 January 2013

Received in revised form 30 May 2013

Accepted 4 June 2013

Available online $\mathrm{xxxx}$

\section{Keywords:}

Aegean domain

North Anatolian Fault Zone

Morphometry

$R / S_{R}$ index

Drainage network

Uplift

\begin{abstract}
A B S T R A C T
While the Plio-Quaternary uplift of the Kazdag mountain range (Biga Peninsula, NW Turkey) is generally acknowledged, little is known about its detailed timing. Partly because of this lack of data, the cause of this uplift phase is also debated, being associated either to back-arc extension in the rear of the Hellenic subduction zone, to transpression along the northern edge of the west-moving Anatolian microplate, or to extension driven by gravitational collapse. Here, we perform a morphometric study of the fluvial landscape at the scale of the Biga Peninsula, coupling the recently developed $R / S_{R}$ analysis of the drainage network with concavity and steepness measures of a set of 29 rivers of all sizes. While the dependence of profile concavity on basin size confirms that the landscape of the peninsula is still in a transient state, the spatial distribution of profile steepness values characterized by higher values for streams flowing down from the Kazdag massif shows that the latter undergoes higher uplift rates than the rest of the peninsula. We obtain a $S_{R}$ value of $0.324 \pm 0.035$ that, according to the relation established by Demoulin (2012), yields an age range of 0.5-1.3 Ma and a most probable value of $0.8 \mathrm{Ma}$ for the time of the last tectonic perturbation in the region. In agreement with the analysis of knickpoint migration in a subset of rivers, this suggests that a pulse of uplift occurred at that time and, corroborated by sparse published observations in the Bayramiç and Çanakkale depressions, that the peninsula was uplifted as a whole from that time. This uplift pulse might have been caused by transient compressive conditions in the Anatolian plate when the Eratosthenes seamount came to subduct beneath the Cyprus arc around the early-to-mid Pleistocene transition (Schattner, 2010).
\end{abstract}

(C) 2013 Elsevier B.V. All rights reserved.

\section{Introduction}

Squeezed between the converging African and Eurasian plates, the Eastern Mediterranean region is an area of active geodynamics where ongoing crustal deformation and high seismicity result from complex interactions between competing forces (Taymaz et al., 2007). Since the Late Cretaceous closure of the Neotethyan basins, its evolution is governed by northward subduction of the African plate along the Hellenic trench in the west and continental collision between Arabia and Turkey in the east (Fig. 1A). Northward motion of the Arabian indenter led to the formation of the Caucasus orogen and caused extrusion of the Anatolian microplate, whose westward escape, accompanied by counter-clockwise rotation, is guided by the North and East Anatolian strike-slip faults. In the same time, in response to slab retreat and, possibly, post-orogenic collapse (Taymaz et al., 2007, and references therein), extension dominated much of the Cenozoic evolution in the Aegean Sea and western Turkey and is still prevailing

\footnotetext{
* Corresponding author at: Dept. of Physical Geography and Quaternary, University of Liège, Liège, Belgium. Tel.: + 32 43665660; fax: + 3243665722.

E-mail address: ademoulin@ulg.ac.be (A. Demoulin).
}

in the whole area, from the Corinth rift (Bell et al., 2009; Floyd et al., 2010 ) to the horsts and grabens of western Turkey (Çiftçi and Bozkurt, 2009; Kurtuluş et al., 2009; Süzen et al., 2006). GPS velocities (Reilinger et al., 2006) show that back-arc extension in the Aegean is currently more rapid than the westward motion of Anatolia, thus accommodating the latter's displacement and still allowing local graben formation.

Within this complex pattern of deformation, northwestern Turkey, and especially the Biga Peninsula are situated just where the westward propagating North Anatolian strike-slip fault meets the North Aegean extensional domain. This region offers therefore an excellent opportunity to explore controversial issues about causes and timing of repeated tectonic uplift since the Miocene (e.g., Altunkaynak and Genç, 2008; Yilmaz, 2008) and to put these uplift episodes in their geodynamic context. However, except for the development of the North Anatolian Fault Zone (NAFZ) in the north (Sengör et al., 2005), the chronology of the Quaternary tectonic evolution of the peninsula remains poorly constrained, as illustrated in the uplifted Kazdag range (Fig. 1B), where no detailed temporal data exist to go beyond general agreement on an overall Plio-Quaternary upward motion. Yet, a better knowledge of the timing and spatial distribution of this uplift and of the associated 

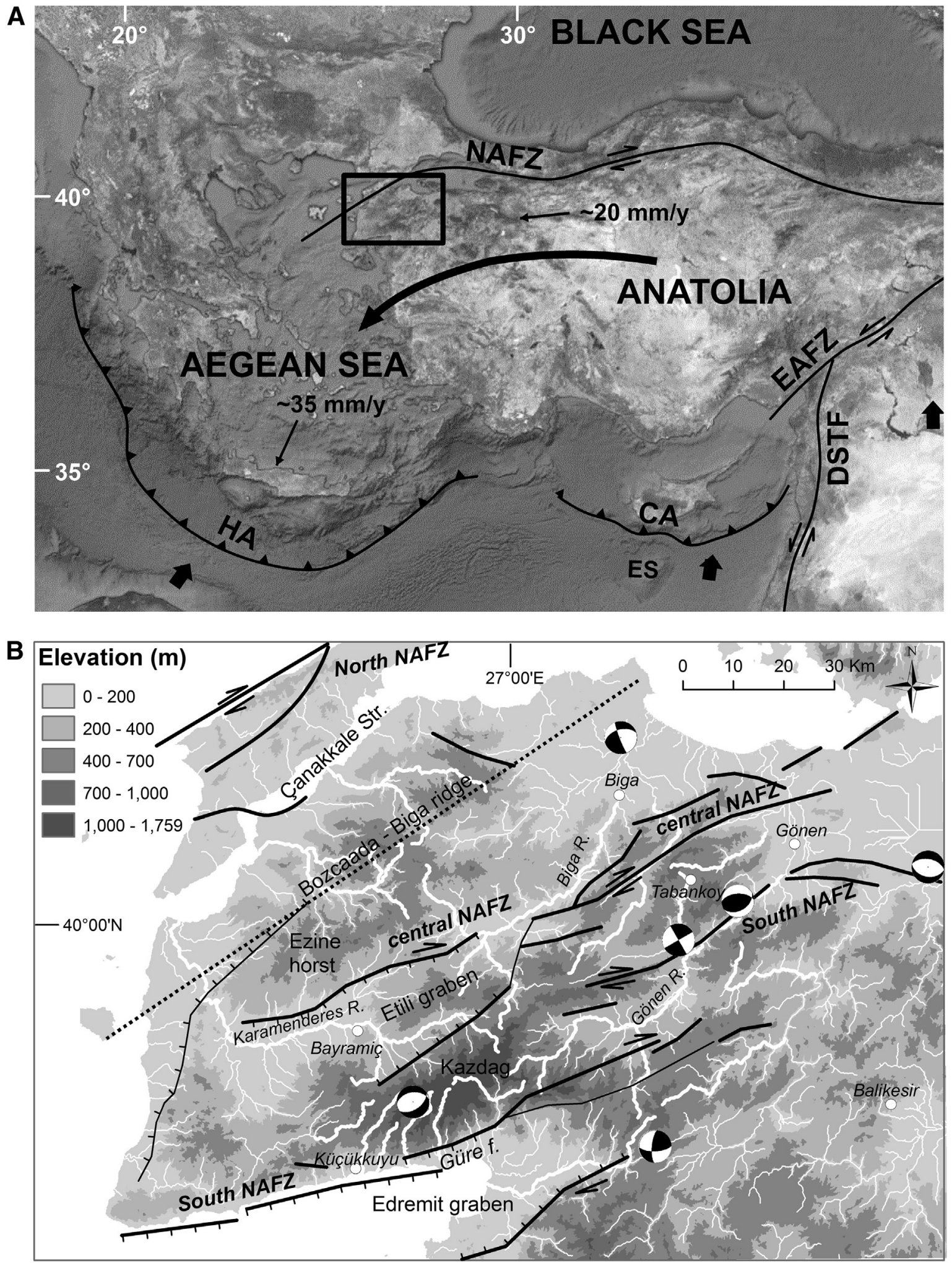

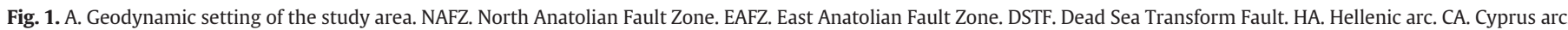

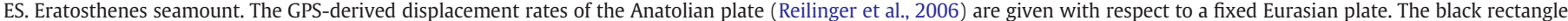

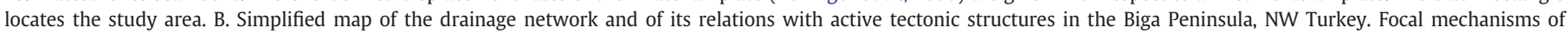
post-1940 $M_{w} \geq 6.0$ earthquakes are located at the respective earthquake epicentres. Barbed lines denote normal faults.

deformation style would be very helpful not only for better constraining the regional Quaternary tectonics, but also for improving seismic hazard assessments that are highly needed in these densely populated areas.
Indeed, although the 1999 Izmit earthquake recently directed much attention on the northern branch of the western termination of the NAFZ in the Marmara region, the seismicity associated with its active 
central and southern branches across the Biga Peninsula is also significant, with several damaging earthquakes of $M_{w} \sim 7$ in the last 70 years (Cavazza et al., 2009; Kürçer et al, 2008) (Fig. 1B).

As Quaternary uplift amounted to a maximum $\sim 0.5 \mathrm{~km}$, lowtemperature thermochronology is of limited use in the analysis of the peninsula's recent denudation (Cavazza et al., 2009), and the best evidence thereof comes from the landscape morphology itself. Among the geomorphological tools most relevant for highlighting short-term variations in Quaternary vertical tectonics, studies of raised marine terraces are often effective in coastal areas (e.g., Cucci, 2004), while those dealing with river terraces are invaluable in unraveling regional uplift and incision histories (e.g., Peters and van Balen, 2007). Marine terraces have so far been studied only along the northern margin of the Biga Peninsula, in the Çanakkale (Dardanelles) area (Yaltırak et al., 2002), and, to our knowledge, the terrace staircase of the rivers draining the interior of the peninsula and especially the Kazdag range has as yet not been discussed, except for very general considerations (Efe, 1994; Efe et al., 2011; Koç, 2007). Consequently, precise age constraints on the regional uplift are almost totally lacking. In this paper, we thus combine a detailed geomorphometric analysis of the regional drainage system's vertical component, i.e., river incision, with modelling of knickpoint migration along river profiles, from which we infer an approximate age for the drainage system's last episode of erosion in response to accelerated uplift. Several papers recently calculated classical morphometric indices to assess the youth of river valley incision in the Kazdag area and they concluded that uplift and fault activity are currently going on (Bayer Altin, 2012; Cürebal and Erginal, 2007), but such simple indices as the SL index of Hack (1973) or measures of concavity and steepness of river profiles can at best provide qualitative information. Therefore, in order to derive more quantitative age estimates of the Biga peninsula/Kazdag range uplift, our morphometric approach will strongly rely on the use of a promising new global landscape metric that provides a synthesizing, scaled measure of river incision. This metric has been devised to describe the scale-dependent 'incision advance' taken by an eroding river with respect to its network of tributaries (Demoulin, 2011) and leads to the definition of an index of regional value that was recently shown to be able to extract time information from the topography (Demoulin, 2012).

\section{Geological and geomorphological setting}

\subsection{Present morphology of the Biga Peninsula}

With mean altitudes of $300-350 \mathrm{~m}$ asl, the Biga Peninsula is mainly a hilly region that progressively rises southward toward the Kazdag area, a range extending over $1100 \mathrm{~m}$ asl, with a few summits culminating above $1700 \mathrm{~m}$ asl (Fig. 1B). Though rock types of highly varying erodibility are exposed to erosion, the distribution of the topographic masses is primarily dictated by the location of active structures, rather than by lithology. The peninsula is characterized by the tectonically controlled NE-SW elongation of its major topographic features, although some lowland areas (e.g., the Bayramiç basin), and especially the southern coastline of the peninsula, display a more E-W trend. The NE direction refers to the strike of the numerous fault segments that compose the central and southern branches of the NAFZ running across the Biga Peninsula (Fig. 1B), and that generally locate the contact between range and lowland. As for the E-W trend, it corresponds to the direction of maximum horizontal stress within the Aegean extensional domain.

Made of basement metamorphic rocks, the $\sim 55-\mathrm{km}$-long Kazdag range is highly asymmetric, opposing gentler slopes that roughly correspond to tilted Neogene surfaces on its northern flank to very steep slopes going down in a few kilometres to the Gulf of Edremit and its eastward onshore prolongation in the Edremit basin to the south. This asymmetry results from the back tilting of the Kazdag horst acting as the footwall of the border faults of the Edremit graben, one of the largest E-W trending grabens of western Anatolia. There, the narrow coastal zone at the foot of the range is occupied by alluvial fans fed by the erosion of the relief. By contrast, the coastal plains on the western and especially northern sides of the peninsula are much wider, notably in the extended Biga and Gönen basins that open to the Marmara Sea in the north. Next to the Kazdag range and its NE forerunners around Tabankoy, the second largest elevated area in the peninsula corresponds to topographic highs up to $800-900 \mathrm{~m}$ asl situated on Oligocene volcanic rocks in the NW, and prolonged to the SW by the lower but sharply delimited Ezine horst at $\sim 500 \mathrm{~m}$ asl (Fig. 1B).

The N-S asymmetry of the topography is reflected by the hydrographic network, the drainage divide of the peninsula following the summit line of the Kazdag, only about $20 \mathrm{~km}$ north of the southern coastline. The southern flank of the massif is thus drained by a number of small parallel streams currently actively incising narrow valleys within the range and flowing into the Gulf of Edremit. The streams flowing down the northern slopes of the Kazdag massif gather in a main collector, the Karamenderes River, which runs from NE to SW, passes across the Bayramiç basin and turns then to the north to finally flow into the southern end of the Çanakkale Strait (Fig. 1B). The opposite half of the wide NE-SW corridor between the Kazdag massif and the NW highs is drained by the Biga River toward the Marmara Sea. Finally, the third major stream in the peninsula, the Gönen River, collects the waters of the southeastern slopes of the Kazdag area and flows along the southern flank of the range before joining also the Marmara Sea in the north. These large rivers display stepped fluvial terraces bearing witness to the regional Quaternary uplift, Efe et al. (2011) identifying for example two levels of high terraces and one low terrace level within the lower Gönen River, which they assign respectively to the Lower-Middle and to the Upper Pleistocene, though without supporting evidence.

In brief, narrow valleys and steep long profiles of streams flowing down the Kazdag range and other elevated hills contrast with wider valleys and well-developed floodplains as soon as larger rivers reach the intervening or coastal lower areas, suggesting that ongoing river incision is the continuation of a well advanced landscape response, a conclusion that the location of knickpoints far upstream in many present-day river profiles also supports.

\subsection{Neogene geodynamic evolution of the Biga Peninsula}

The recent uplift of the Biga Peninsula and especially of the Kazdag area, which the drainage system is still currently responding to by incision and terrace development, belongs to the youngest of several phases of extension and uplift that affected western Turkey since the Miocene. Based on Rb/Sr data, Okay and Satir (2000) have shown that the metamorphic core complex of Late Oligocene age that is exposed in the uplifted Kazdag area was rapidly exhumed from $\sim 14$ to $7 \mathrm{~km}$ depth during the phase of $\mathrm{N}-\mathrm{S}$ extension that developed in the back-arc area of the Hellenic subduction zone in the Early Miocene ( $20 \mathrm{Ma}$ ). According to Bonev and Beccaletto (2007), the contemporaneous calc-alkaline magmatism of the Biga Peninsula bears also witness to this extension. Recently, new apatite fission track data yielded slightly younger ages (14-17 Ma, i.e., early Middle Miocene) for this first episode of exhumation and uplift of the Kazdag (Cavazza et al., 2009). Different models have been proposed to explain midCenozoic and later extension in the Aegean domain, namely orogenic collapse (Seyitoğlu and Scott, 1991, 1996), active asthenospheric upwelling (Altunkaynak and Genç, 2008), and rollback of the Hellenic trench (Okay and Satir, 2000), the latter of which is now accepted as the main cause by most researchers (Armijo et al., 1999; Dilek, 2006; Jolivet and Brun, 2010). Moreover, in their recent synthesis of the Cenozoic geodynamic evolution of the Aegean domain, Jolivet and Brun (2010) invoked delamination and possible slab tearing under 
western Turkey, i.e., processes providing dynamic support of the topography, and thus also contributing to uplift.

Lower and Middle Miocene clastic rocks deposited north and south of the uplifted massif are fine-grained lacustrine turbidites (Okay and Satir, 2000), indicating that, after a phase of rapid exhumation and erosion, the Kazdag likely remained a low-lying emerged area for a long time (Yilmaz et al., 2010), during which an erosion surface now observed at elevations of $1000-1100 \mathrm{~m}$ asl in the same area is also assumed to have been elaborated (Erol, 1982).

Near the Mio-Pliocene transition, uplift of the Kazdag area and exhumation of its metamorphic core complex resumed. Okay and Satir (2000) think that this occurred during the Pliocene because the Kazdag gneisses appeared then at the surface and are found for the first time in Plio-Quaternary conglomerates and sandstones accumulated in the Bayramiç area, to the NW of the massif (Siyako et al., 1989). As shear deformation related to the propagation of the NAFZ in western Turkey commenced during the Plio-Quaternary (Sengör et al., 2005), Okay and Satir (2000) suggest that this new phase of Kazdag uplift was caused by transpression in an area of overstepping strike-slip faults belonging to the central (Biga fault) and southern (Güre fault, border faults of the Edremit graben) branches of the western end of the NAFZ, which splay across the Biga peninsula (Barka and Kadinsky-Cade, 1988; Yilmaz et al., 2010) (Fig. 1B).

However, the evolution is arguably somewhat more complicated than this. The interrupted development of the Middle Miocene erosion surface (Erol, 1982) and deformation of the Lower and Middle Miocene cover rocks to the SW of the Kazdag (Yilmaz and Karacik, 2001) suggest that the uplift probably started earlier, sometime in the early Late Miocene. Indeed, in the same time, the resumption of the Biga Peninsula volcanism after a waning period between 15 and $11 \mathrm{Ma}$ (Altunkaynak and Genç, 2008) is probably linked to reactivated slab retreat at the Hellenic trench and renewed $\mathrm{N}-\mathrm{S}$ back-arc extension around $12 \mathrm{Ma}$ (Meulenkamp et al., 1988). However, the resulting denudation was apparently insufficient to bring the Kazdag metamorphic rocks to the surface by that time.

After this brief uplift episode in the early Late Miocene, sedimentation was restricted mainly to NE-SW trending grabens (e.g., the Etili graben) during the Late Miocene and the Early Pliocene (Yilmaz and Karacik, 2001), suggesting that, even if at a slower pace, the intervening areas were still uplifting within a continued $\mathrm{N}-\mathrm{S}$ extensional regime (Jolivet and Brun, 2010). The resulting rugged structural topography was then partly beveled by a phase of intense erosion during the Late Pliocene (Yilmaz and Karacik, 2001), which brought the Kazdag gneisses to the surface, after which they appeared as sediments in the adjacent grabens (Okay and Satir, 2000). This last phase of regional denudation corresponds to the uplift event inferred by Erol (1982) from the current position of another erosion surface, now at elevations between 500 and $700 \mathrm{~m}$ asl around the Kazdag range, and that Yilmaz (2008) describes as truncating Upper Miocene and Lower Pliocene lacustrine limestones.

This youngest uplift phase is assumed to have been active until now and to have caused the ongoing denudation of the Kazdag massif and surrounding areas, whose erosion products, including Upper Miocene to Lower Pliocene sediments, were accumulated in Late Pliocene-Quaternary, E-W trending grabens, and especially in the Gulf of Edremit, to the south of the Kazdag. The specific character of this episode results from the propagation of the NAFZ at the western tip of the Anatolian plate affected by complex block rotations (Piper et al., 2010; Yilmaz et al., 2010), and from the resulting interactions with the Aegean $\mathrm{N}-\mathrm{S}$ extensional regime, whose persisting influence is underlined by the development of E-trending grabens (Gürer et al., 2006). Moreover, uplift persisted then under changing stress regimes, and namely through the early-to-mid Pleistocene tectonic transition noted by Schattner (2010) in the whole eastern Mediterranean realm and characterized in Anatolia and the Aegean Sea by a short-lived compressional phase around $1 \mathrm{Ma}$ followed by renewed extension in a slightly changed direction.

In summary, three phases of uplift may be identified during the Neogene in the Biga Peninsula in relation with episodic extension in the Aegean realm (Cavazza et al., 2009). While the Early Miocene to early Middle Miocene phase left no trace in the current morphology, the early Late Miocene phase stopped the evolution of an erosion surface currently raised at 1000-1100 m asl, and the Late Pliocene to Present phase in turn interrupted the bevelling of a younger, late Early Pliocene, erosion surface now found at 500-700 $\mathrm{m}$ asl. The amount of uplift recorded by the Kazdag during individual phases may be roughly estimated from the difference in present-day altitudes between these surfaces, which yields figures of 400-500 and 500-700 m respectively for the early Late Miocene and Plio-Quaternary uplifts. Moreover, as the current denudation phase is still in the stage of valley incision, the preservation of fluvial terraces within the valleys allows tracking second-order variations in uplift rate within the last period of Plio-Quaternary uplift. Though not much detailed, the reconstructed terrace staircase seems notably to have recorded an acceleration of the Kazdag uplift in the Middle Pleistocene (Efe, 1994; Erol, 1981, 1982; Koç, 2007).

\section{Methods}

Our analysis of the Quaternary morphological evolution of the Biga Peninsula is essentially based on a set of morphometric measurements. We first calculate two classical topographic indices characterizing individual river profiles of different sizes, namely profile concavity and steepness (Flint, 1974; Wobus et al., 2006), and turn then to the determination of the new $S_{R}$ index proposed by Demoulin (2011), which describes the stage reached by the whole landscape in its response to the last perturbation, assumed to be of tectonic origin. We also exploit knickpoints present in many river long profiles and model their retreat rate in order to derive an age range consistent with realistic values of the propagation rule's parameters.

\subsection{Profile concavity and steepness}

The concavity $\theta$ of a river profile is simply given by the slope of the $\log -\log$ relation between channel gradient $S$ and contributing drainage area $A$, while the intercept of this relation is defined as the profile steepness $k$. However, steepness will in general rather be expressed as $k_{s}=10^{k}$, i.e., the coefficient of the empirical power function between $S$ and $A$

$S=k_{S} A^{-\theta}$.

It has been shown that, at least for steady-state rivers, steepness $k_{s}$ is a function of rock uplift rate $U$ (or, equivalently, of the uplift amount since a given time) (Snyder et al., 2000). However, as this index is also strongly dependent on profile concavity, qualitative inferences on uplift rate are preferably drawn from normalized steepness values $k_{s n}$, usually obtained by recalculating $\log S-\log A$ correlations with a reference concavity $\theta_{\text {ref }}$ fixed on the regional average of the observed concavities (Wobus et al., 2006). Here, we will moreover consider an alternative expression of normalized steepness, which we shall simply equate with the residuals of the correlation between $k$ and $\theta$.

\section{2. $R / S_{R}$ analysis}

The landscape index $S_{R}$ corresponds to the first derivative of the regression function linking a complex landscape metric $R$ to the natural logarithm of drainage area $A$ (Demoulin, 2011). The $R$ metric can be calculated for fluvial catchments of every size and takes the form of a ratio of two-by-two differences between the normalized 
hypsometric integrals of the classical basin hypsometric curve $H_{b}$, the drainage network hypsometric curve $H_{n}$, and the trunk stream long profile $H_{r}$ (Fig. 2). The drainage network hypsometric curve represents the percentage of the network pixels (or cumulated length) whose altitude is higher than every given value (standardized with respect to the catchment's altitudes). The $R$ metric thus includes information related to three nested morphological levels respectively indicative of the long-, middle-, and short-term components of the landscape response,

$R=\frac{\int_{0}^{1}\left(H_{n}-H_{r}\right) d l^{*}}{\int_{0}^{1}\left(H_{b}-H_{n}\right) d l^{*}}$

where $l^{*}$ is the dimensionless expression of length (for $H_{r}$ and $H_{n}$ ) or area (for $H_{b}$ ). This raw measure of $R$ must then be corrected for the effect of the drainage network's hierarchical structure. Indeed, the size contrast between trunk and tributaries controls, through the degree of drainage area change at junctions, the pattern of migration rates of the erosion front within the system, and thus affects the behaviour of the metric (Demoulin, 2012). As these size contrasts are tightly related to the catchment shape, and especially elongation $\mathrm{E}$ (in an elongated basin, many very small tributaries typically flow directly within a much larger trunk stream), we apply a correction factor $1 / \sqrt{ } \mathrm{E}$, where $\mathrm{E}$ is calculated as $4 A /\left(\pi * L_{b}{ }^{2}\right)$, with $L_{b}=$ maximal length of the catchment, measured from its outlet.

The composite nature of $R$ incorporates the fact that the system's transient response to a base level change occurs primarily through the propagation of a wave of erosion travelling from any catchment outlet upstream through their drainage network, and consequently makes the metric able to extract time information from the landscape shape. Therefore, this metric offers another way to tackle the time versus rate issue of knickpoint retreat, which most authors have so far addressed by using more or less well constrained time data to infer rates of knickpoint migration and incision (e.g., Berlin and Anderson, 2007; Crosby and Whipple, 2006; Schildgen et al., 2012; Whittaker and Boulton, 2012) and, in some cases, response time estimates (Whittaker et al., 2007), rather than deriving time information from the observed progress of knickpoint propagation. Demoulin (2011) has shown that, following a base level lowering and the subsequent identical increase in all three integrals, which leaves $R$

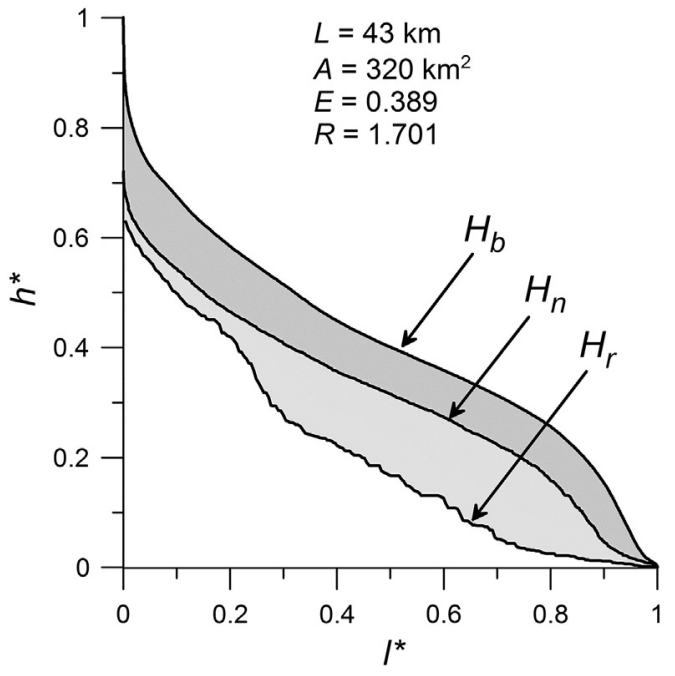

Fig. 2. Description of the $R$ metric components for river \#21 of our data set: $l^{*}=l / l_{0}$, with $l_{0}=$ length of the river, cumulative length of its drainage network, and basin area respectively for $H_{r}, H_{n}$, and $H_{b} ; h^{*}=h / h_{0}$, with $h_{0}=$ basin relief. $H_{b}, H_{n}$ and $H_{r}$ are the hypsometric curves, i.e., cumulative distributions of altitudes, of the basin, the drainage network, and the trunk stream $\left(H_{r}\right.$ is therefore simply the trunk stream long profile) $E$ describes the basin's elongation. initially unchanged, the initial stage of a catchment's response is characterized by a marked decrease in $\int H_{r}$, while $\int H_{n}$ diminishes only slightly and $\int H_{b}$ hardly changes, leading to a rapid increase in $R$. Then, in the middle term $\left(>10^{4}-10^{5} \mathrm{yr}\right)$, the low courses of trunk stream and major tributaries having reached a new equilibrium, erosion proceeds at a progressively slower pace in the upper course of the trunk while it propagates simultaneously in an increasing number of tributaries and sub-tributaries, so that the decrease in $\int H_{r}$ slows down and, concurrently, that in $\int H_{n}$ accelerates strongly. In the same time, $\int H_{b}$ is still more or less unaffected. This stage of the evolution, which lasts a few million years in areas of moderate uplift and relief (Whipple, 2001; Whittaker et al., 2007), depending on factors such as rock resistance or climate, and results in a slow decrease in $R$ with time, lends all its interest to the metric, especially because the resulting dating potential covers the time scales where most other methods fail.

However, besides time, the size of the contributing drainage area appears to be another primary control on $R$ and this effect must be removed in order to isolate the temporal information. Fortunately, the logarithmic function linking the metric to $A$ is typical of each region of uniform uplift time, and Demoulin (2011) has shown that the derivative $S_{R}$ of the function $R=\mathrm{f}(\ln A)$ is theoretically expected to evolve also continuously with time during the transient response to an uplift signal (that may take the form of either a pulse or a step increase in uplift rate), following a temporal pattern very similar to that of the $R$ changes. Therefore, this derivative may be used as another time indicator, this time free of basin size effect, and, based on data from 9 uplifted regions worldwide where the time of the last increase in uplift rate was independently known, Demoulin (2012) recently proposed an empirical quantitative relation linking $S_{R}$ to the age of uplift (in million years) and reading

$t=0.009 * S_{R}{ }^{-4}$.

Though having already provided encouraging results (Demoulin, 2011, 2012), this method is still in its infancy, and future developments should allow overcoming some technical limitations and understanding the potential role of as yet unexplored external controls. Firstly, as it requires estimating the relation between $R$ and catchment size, and as data of rivers with catchment larger than $150 \mathrm{~km}^{2}$ are needed to stabilize this relation, the uplifted area under study must be large enough to encompass several such rivers, ideally including a few rivers with drainage area above $1000 \mathrm{~km}^{2}$, which is the case of the Biga Peninsula (Table 1).

Secondly, while the effects of random variations of factors controlling incision (like, e.g., contrasted rock resistance) generally cancel mutually in the relation between $R$ and $\ln A$ and the interregional differences in such factors are damped to some extent by their intra-regional variability (Demoulin, 2012), there should not be systematic biases in their spatial distribution, which may then cause systematic differences in erosional behaviour between trunk stream and tributaries. Here, we make the reasonable assumption that, having excluded the Neogene basins from the analysis, contrasts in rock resistance among the basement and volcanic rocks of the uplifted areas are not strong enough to perturb significantly the results.

Thirdly, noise in the $R$ measurements may also arise when the tributary network of a catchment departs significantly from a uniform spatial distribution, biasing the $H_{n}$ value and, consequently, the $R$ estimate. Such a strong bias is generally suspected for catchments displaying a marked pear-like shape, opposing a narrow upper or lower half to a wide other one, where the correction for catchment elongation is ineffective. Therefore, beyond uniform coverage of the study area, the two main selection criteria for rivers to enter our data set were (1) contribute to a balanced representation of the whole range of basin sizes present in the region and (2) not show a highly disequilibrated spatial distribution of its tributaries. 
Table 1

Morphometry of the rivers studied in the Biga Peninsula.

\begin{tabular}{|c|c|c|c|c|c|c|c|c|c|c|c|}
\hline Stream & $L(\mathrm{~km})$ & $A\left(\mathrm{~km}^{2}\right)$ & $\theta$ & $k$ & $k_{s n}$ & Res. $k(\theta)$ & $\int H_{b}$ & $\int H_{n}$ & $\int H_{r}$ & $E$ & $R$ \\
\hline 1 & 22.9 & 78 & 0.303 & 0.821 & 2233.6 & 0.121 & 0.484 & 0.382 & 0.336 & 0.260 & 0.877 \\
\hline 2 & 20.8 & 61 & 0.100 & -0.533 & 2697.7 & 0.188 & 0.515 & 0.393 & 0.332 & 0.291 & 0.934 \\
\hline 3 & 12.4 & 30 & 0.412 & 1.736 & 2243.9 & 0.273 & 0.497 & 0.382 & 0.315 & 0.304 & 1.072 \\
\hline 4 & 109.8 & 1775 & 0.810 & 4.522 & 1219.0 & 0.272 & 0.176 & 0.135 & 0.080 & 0.465 & 1.967 \\
\hline 5 & 46.1 & 502 & 0.784 & 4.330 & 1574.0 & 0.262 & 0.254 & 0.186 & 0.124 & 0.510 & 1.295 \\
\hline 6 & 15.4 & 82 & 0.551 & 2.469 & 1406.0 & 0.032 & 0.306 & 0.224 & 0.142 & 0.635 & 1.255 \\
\hline 7 & 22.5 & 131 & 0.651 & 3.061 & 1009.3 & -0.076 & 0.408 & 0.262 & 0.171 & 0.447 & 0.939 \\
\hline 8 & 89.1 & 1344 & 0.594 & 2.751 & 1458.8 & 0.013 & 0.293 & 0.216 & 0.121 & 0.373 & 2.020 \\
\hline 9 & 71.6 & 970 & 0.756 & 3.957 & 1030.4 & 0.085 & 0.265 & 0.194 & 0.100 & 0.478 & 1.914 \\
\hline 10 & 49.5 & 522 & 0.778 & 4.148 & 1124.6 & 0.122 & 0.309 & 0.223 & 0.119 & 0.499 & 1.713 \\
\hline 11 & 55.3 & 305 & 0.413 & 1.078 & 799.8 & -0.392 & 0.394 & 0.285 & 0.208 & 0.267 & 1.348 \\
\hline 12 & 26.1 & 230 & 0.609 & 2.889 & 1399.6 & 0.046 & 0.356 & 0.265 & 0.173 & 0.771 & 1.151 \\
\hline 13 & 12.5 & 41 & -0.387 & -3.881 & 2612.2 & 0.249 & 0.597 & 0.490 & 0.423 & 0.531 & 0.872 \\
\hline 14 & 37.0 & 295 & 0.482 & 1.797 & 1124.6 & -0.156 & 0.411 & 0.314 & 0.229 & 0.463 & 1.288 \\
\hline 15 & 19.6 & 50 & 0.349 & 0.866 & 1042.3 & -0.156 & 0.452 & 0.324 & 0.266 & 0.291 & 0.839 \\
\hline 16 & 33.5 & 265 & 0.641 & 2.971 & 975.0 & -0.096 & 0.384 & 0.277 & 0.183 & 0.586 & 1.148 \\
\hline 17 & 18.7 & 46 & 0.599 & 3.168 & 3090.3 & 0.395 & 0.484 & 0.344 & 0.303 & 0.219 & 0.621 \\
\hline 18 & 24.9 & 115 & 0.274 & 0.394 & 1472.3 & -0.103 & 0.457 & 0.355 & 0.270 & 0.348 & 1.412 \\
\hline 19 & 8.0 & 21 & 0.352 & 1.206 & 1648.2 & 0.163 & 0.541 & 0.323 & 0.271 & 0.483 & 0.343 \\
\hline 20 & 47.0 & 457 & 0.588 & 2.608 & 1116.9 & -0.088 & 0.367 & 0.269 & 0.152 & 0.534 & 1.619 \\
\hline 21 & 43.3 & 317 & 0.430 & 1.316 & 979.5 & -0.273 & 0.411 & 0.312 & 0.206 & 0.389 & 1.701 \\
\hline 22 & 16.3 & 87 & 0.387 & 1.195 & 1227.4 & -0.093 & 0.454 & 0.331 & 0.206 & 0.554 & 1.365 \\
\hline 23 & 20.5 & 105 & 0.332 & 0.663 & 885.1 & -0.240 & 0.418 & 0.304 & 0.213 & 0.626 & 1.009 \\
\hline 24 & 10.9 & 46 & 0.248 & 0.198 & 1061.7 & -0.117 & 0.442 & 0.330 & 0.245 & 0.588 & 0.990 \\
\hline 25 & 9.1 & 27 & 0.412 & 1.420 & 1066.6 & -0.043 & 0.376 & 0.236 & 0.212 & 0.535 & 0.223 \\
\hline 26 & 8.1 & 24 & 0.608 & 2.773 & 1039.9 & -0.063 & 0.455 & 0.235 & 0.161 & 0.509 & 0.478 \\
\hline 27 & 15.2 & 58 & 0.675 & 3.156 & 843.3 & -0.149 & 0.334 & 0.219 & 0.159 & 0.431 & 0.802 \\
\hline 28 & 17.0 & 65 & 0.365 & 1.082 & 1333.5 & -0.052 & 0.382 & 0.280 & 0.198 & 0.476 & 1.166 \\
\hline 29 & 25.4 & 225 & 0.660 & 3.058 & 853.1 & -0.142 & 0.323 & 0.241 & 0.181 & 0.801 & 0.818 \\
\hline
\end{tabular}

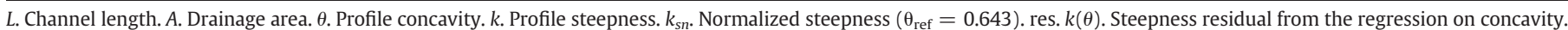

$\int H_{b}, \int H_{n}, \int H_{r}$. Basin, drainage network and trunk stream hypsometric integrals. E. Basin elongation. $R$. Computed landscape metric (see text).

Finally, the parameterization of the quantitative relation used to derive age information from the $R / S_{R}$ measurements is ensured only under the assumption of en-bloc uplift or, at least, of an uplift area clearly delimited by breaks in slope that cause the formation of knickpoints in the drainage network. The often fault-bounded uplifted areas of the Biga Peninsula, displaying sharp topographical breaks toward the surrounding seas and adjacent basins satisfy this condition. We also assume that discrete structures within the study area were only moderately active, thus inducing at worst limited noise in the data. Moreover, preliminary modelling work has shown that other uplift geometries lead to a similar power-law relation between time and $S_{R}$ (Croissant, 2012) and suggests that a strong departure from the en-bloc uplift model is needed to modify significantly the calibration of the relation and the inferred times.

Our data set is composed of 29 rivers ranging from small thirdorder streams to all major rivers draining the peninsula, thus including the Karamenderes, Biga and Gönen rivers (Fig. 3A). Most small rivers taking their source around the Kazdag summits are also included. Streams that flow for a significant part of their course within basins between the uplifted areas have been discarded. For the same reason, the $R$ values of the Biga and Gönen rivers refer only to their course from source to entrance in the respective Biga and Gönen basins (see in Fig. 3A the stream portions used for $R$ calculations). As the rivers of the data set have drainage areas in the range $10^{7.3}-10^{9.3} \mathrm{~m}^{2}$, all the metrics we used could be satisfactorily estimated from the SRTM 3" digital elevation model in its 'filled' version 2, available from the CGIAR-CSI (http://srtm.csi.cgiar.org/). The SRTM data cover all land area between latitudes $60^{\circ} \mathrm{N}$ and $60^{\circ} \mathrm{S}$ with a resolution of $3 \times 3$ arc sec, which we resampled here to obtain square pixels of $90 \times 90 \mathrm{~m}$. Data extraction was carried out with ArcMap 9.3.1, first-order streams of the drainage network being defined to start for catchment area $>0.5 \mathrm{~km}^{2}$. Channel slope has been calculated from the elevations of channel pixels only, using a 15 pixels smoothing window in order to reduce the data noise to an acceptable level and not to bias the concavity and steepness estimates. The method used to obtain the hypsometric curves and integrals of basin, drainage network and trunk stream was described in detail by Demoulin (2011). Despite the rather poor resolution of the data, the induced uncertainty on $R$ has been empirically shown not to exceed a few percents. Its effect on $S_{R}$ is small and remains within the standard error on the index as calculated from the regression of $R$ on $\ln A$.

\subsection{Knickpoint propagation modelling}

A number of rivers in our data set display knickpoints in their current long profile. Well-defined knickpoints, identified as sharp convexities interrupting otherwise concave-up profiles, have been located in 14 rivers (Fig. 3A). We exploit them here in an attempt to obtain independent indication on the time of the last uplift signal, which is assumed to have caused their creation and migration. As most knickpoints are observed in middle- to small-sized rivers flowing with steep gradients down uplifted areas, the detachmentlimited model based on the unit stream power law, a model relevant for bedrock channel erosion (Whipple and Tucker, 1999), is adequately used here. In its simplest form, neglecting for example all sediment load effects, this model states that

$$
E=K A^{\mathrm{m}} S^{\mathrm{n}}
$$

where $E=$ erosion rate, and $\mathrm{m}, \mathrm{n}$ and $\mathrm{K}$ are parameters, $\mathrm{K}$ describing erosional efficiency. The value of $n$ is mostly estimated between 0.7 and 1 (e.g., van der Beek and Bishop, 2003) and commonly taken as 1 in the analysis of knickpoint data sets (e.g., Berlin and Anderson, 2007), in which case derivation of the stream power law yields a kinematic wave equation for the celerity $C$ of upstream propagation of knickpoints

$C=\mathrm{K} A^{\mathrm{m}}$ 
This is consistent with the sharp profile of many knickpoints observed in the upstream reaches of rivers in the Biga Peninsula, which suggests a prevailing advective component of migration, and we consequently assume that $\mathrm{n}=1$. However, whereas such modelling of knickpoint retreat generally aims at parameter estimation using existing time constraints, we are here rather interested in time estimation. We model therefore knickpoint propagation under different time constraints between 0.1 and $3 \mathrm{Ma}$, with the purpose of comparing the parameter (especially, K) values obtained under these assumed ages with values mentioned in the literature for regions of similar climatic and tectonic settings. A subsidiary aim is also to test the quality of the model fit and ascertain whether the knickpoint data set on which it relies is homogeneous, bearing then witness to a simultaneous signal throughout the study area.
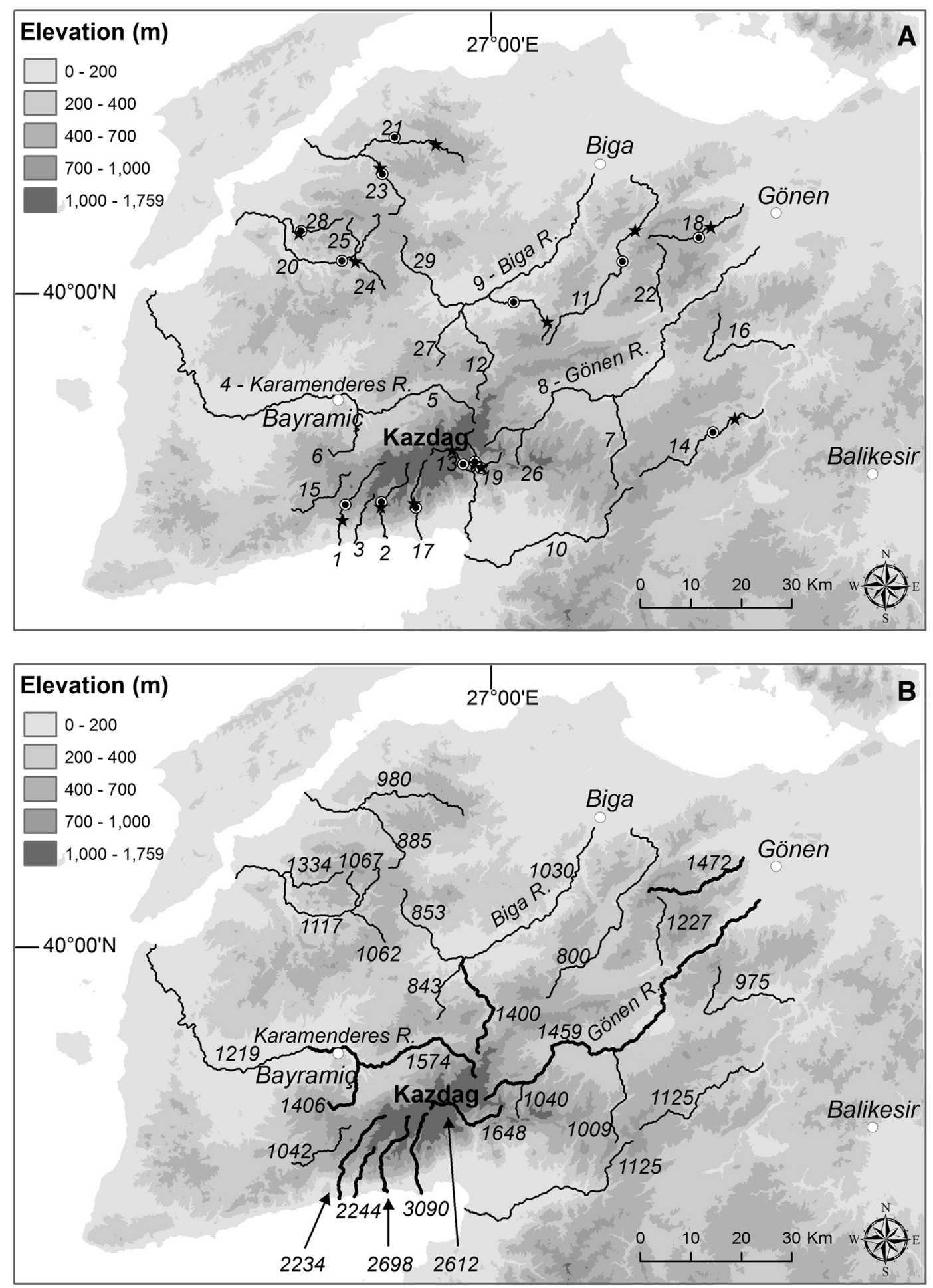

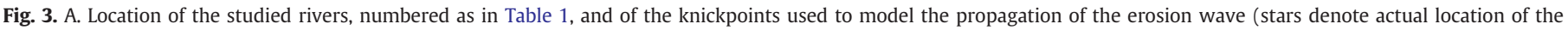

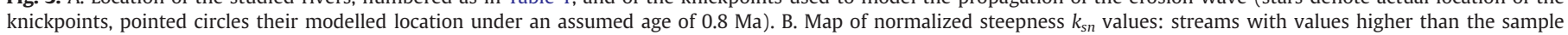
mean appear as thick lines. C. Map of residual steepness values (after removal of the correlation with $\theta$ ): streams with positive residuals appear as thick lines. 


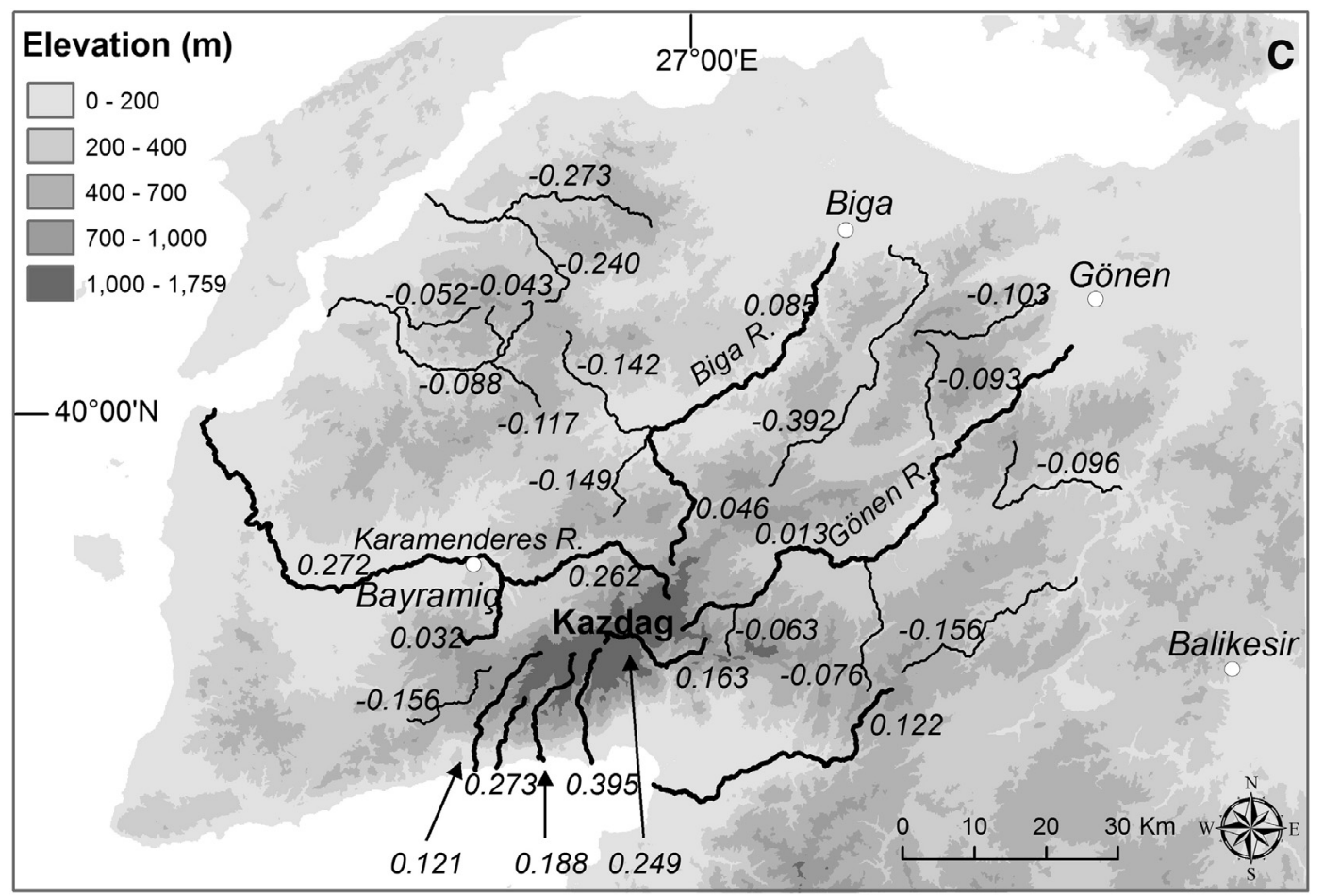

Fig. 3 (continued).

\section{Results}

\subsection{Concavity/steepness analysis}

All morphometric indices obtained for the 29 studied rivers are presented in Table 1. With the exception of one outlier, the profile concavity values are in the range $0.100-0.810$ with a mean of 0.475 , hardly different from the value of $\sim 0.5$ often expected at steady state. More instructive is the large dispersion of the concavity data $(\sigma=0.245)$, whose cause is easily identified in the dependence of profile concavity on size of the river (Fig. 4). Indeed, concavity, which corresponds mathematically to the slope of the log-log relation between channel gradient $S$ and drainage area $A$, appears here to be itself significantly linked to basin size, by an expression that adjusts to

$\theta=0.25 * \log _{10} A-0.06$

with $\mathrm{n}=29$ and $\mathrm{r}=0.55, A$ being expressed in $\mathrm{km}^{2}$. Larger rivers display higher profile-averaged concavity than smaller ones because they responded faster to the perturbation and propagated the transient zone of steep channel gradients proportionally farther upstream in their profile. This dependence of profile concavity on drainage area thus indicates that the drainage system is in a fairly advanced phase of adjustment after the last tectonic perturbation but has not yet reached a new equilibrium. Incidentally, this underlines the often overlooked fact that, when dealing with rivers in actively uplifting areas, the assumption of steady state has to be carefully evaluated before interpreting profile concavity. One will further note that the same remark is often valid for other morphometric indices, and notably for the commonly used basin's hypsometric integral (Chen et al., 2003). In the Biga Peninsula, the basin integral (Table 1) is for instance still more strongly related to basin size by

$\int H_{b}=-0.13 * \log _{10} A+0.68$ $(\mathrm{n}=29, \mathrm{r}=0.76)$ (Fig. 4), so as are also the drainage network and trunk stream integrals (respectively with $r=0.58$ and 0.66 ). The dependence of basin integral on catchment size, which has been shown not to exist at steady state (Cheng et al., 2012; Walcott and Summerfield, 2008), confirms that the transient response of the Kazdag area to uplift is not yet completed. Though the enhancement of this relation between basin integral and drainage area also depends on methodological factors, such as the location of the sampled basins of different sizes with respect to the regional topographic envelope, this stresses that basin size is a main control on many morphometric indices that describe the drainage network or its individual components in transient settings.

Finally, it is worth noting that, beyond the regional correlation between $\theta$ and $A$ (Eq. (6)) showing that the system is still far from adjusted, an analysis of the residuals of the regression, and especially a search for patterns in their spatial distribution, did not provide any indication of another control on intra-regional variations of $\theta$.

As indicated earlier, steepness $k_{s}$ values contain uplift rate information. This is at least true for equilibrium profiles, as the steady-state expression of detachment-limited fluvial erosion models may read as

$S=\left(\mathrm{UK}^{-1}\right)^{1 / \mathrm{n}} A^{-\mathrm{m} / \mathrm{n}}$

where the factor $\left(\mathrm{UK}^{-1}\right)^{1 / \mathrm{n}}$ equates $k_{s}$ and $\mathrm{m} / \mathrm{n}=\theta$ (see Whipple and Tucker (1999) for the nondimensional equivalent of Eq. (8)). Fortunately, normalization of $k_{s}$ removes its dependence on $\theta$ and thus also the effect of profile disequilibrium on it, so that $k_{s n}$ values may be used to identify spatially variable uplift rates in transient conditions. A reference concavity $\theta_{\text {ref }}$ of 0.643 was obtained for the Biga Peninsula from a regression on the data set regrouping all $S$ and $A$ values of the 29 studied streams (but note that any other reference value would have had the same effect of fixing the influence of concavity). However, another easy way of getting rid of the dependence of steepness on concavity is to perform a residual analysis of the regression of the former on the latter. Both sets, respectively of normalized and residual steepness data, yielded approximately the same subset of highest values 


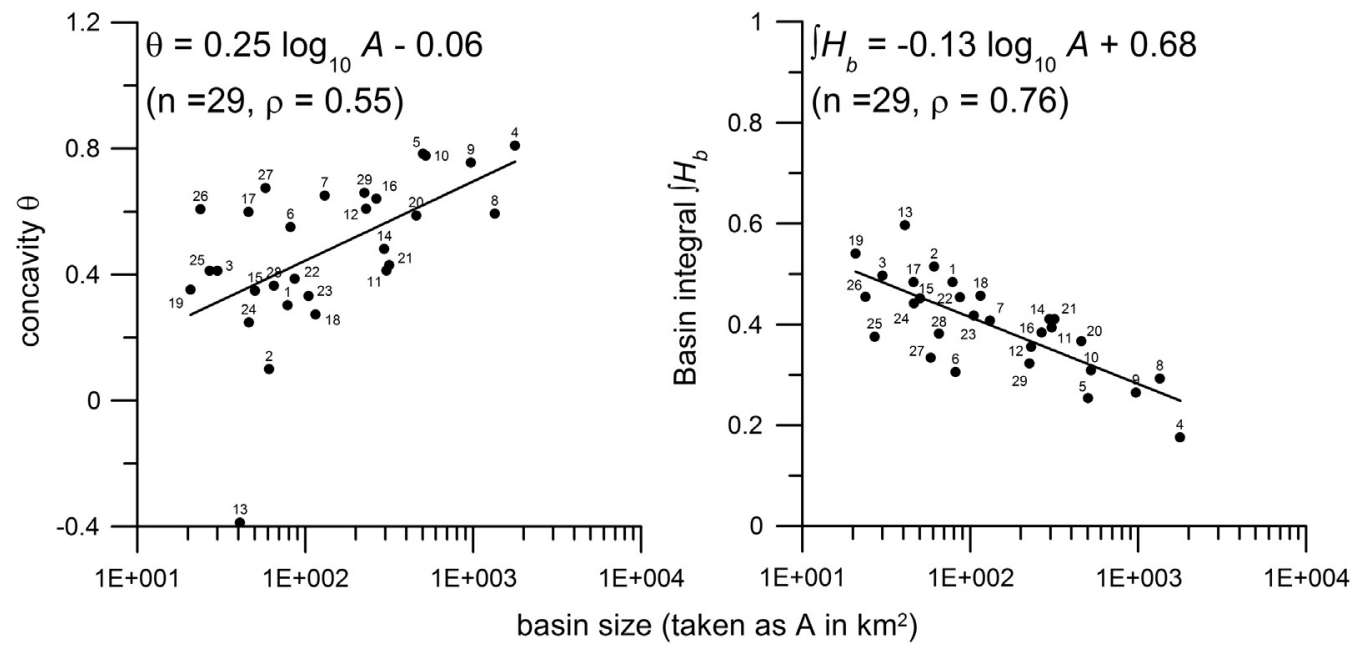

Fig. 4. Correlations of long profile concavity $\theta$ and basin's hypsometric integral $\int H_{b}$ with basin size for a sample of rivers of the Biga Peninsula.

regrouping streams that take their source close to the Kazdag summits (Fig. 3B and C). This clearly points to uplift rates higher in this area than in the rest of the peninsula, something that was in fact already obvious from the topography. The distributions of both measures of steepness confirm this distinction (Fig. 5) and show no other distinguishable subset of values, most probably because the degree of differential uplift is much less marked outside the Kazdag massif sensu stricto. A comparison of the two distributions also suggests that steepness residuals might be slightly more efficient than the usually calculated normalized steepness in separating areas of different uplift rates.

\section{2. $R / S_{R}$ analysis}

Taking into account all rivers of the data set (Table 1 ), we obtained the following relation between $R$ and basin size

$R=0.324 * \ln \mathrm{A}-0.440$

with A expressed in $\mathrm{km}^{2}$ (Fig. 6). This relation expresses the fact that, following a base level lowering, the change in $R$ of any catchment is first governed by the contrast in velocity with which their trunk stream and tributaries respond by regressive erosion. Higher contrasts causing greater increases in $R$ in larger catchments result in a rapid initial steepening of the relation's slope, i.e., an increase in the $S_{R}$ index. Then, in the middle-term, further propagation of the erosion wave in the tributaries and sub-tributaries leads to a progressive decrease in $R$ at a rate that is likewise dependent on catchment size, so that $S_{R}$ now gradually decreases with time. The value of the $S_{R}$ index and its associated error are here of $0.324 \pm 0.035$ at the $95 \%$ confidence level. Referring to the time- $S_{R}$ relation established by Demoulin (2012) (Eq. (3)), this provides an age range of 0.5-1.3 Ma and a most probable value of $0.8 \mathrm{Ma}$ for the time of the last tectonic perturbation in the Biga Peninsula. However, although we limited our analysis to river courses outside the main basins, the largest rivers of the data set (especially the Karamenderes, Gönen, Biga, and the river draining the Edremit basin) still include sections running across hardly uplifted, or even subsiding, inter-range basins (Fig. 1). As the presence of such sections might affect the calculated $\int H_{r}$ and, consequently, the $R$ value of these rivers, we also determined a regional $S_{R}$ value of $0.29 \pm 0.05$ from a reduced data set $(n=25$, excluding the four mentioned streams). Beyond the fact that the obtained index values and the associated times are not statistically different, we consider that the age derived from the whole data set is more reliable because including the largest rivers in the data set widens considerably the range of basin sizes, thus allowing $S_{R}$ to be statistically better defined. Furthermore, Demoulin (2012) suggested that rock resistancedependent variations in erosion rate are probably only a second-order control on the parameterization of the relation between $S_{R}$ and time, and thus on age estimates, because intra-regional variability in bedrock erodibility largely reduces the interregional variations of average rock resistance. This is particularly true for the Biga Peninsula, whose substrates are in the range of those displayed by the regions entering the definition of the $t=\mathrm{f}\left(S_{R}\right)$ relation, with a variability that is assumed to average to a regional rock strength in the central part of the spectrum. Likewise, the total absence of correlation between profile normalized steepness $k_{s n}$ (indicative of uplift rate) and $R$ tends to confirm the independence of $S_{R}$ on $U$. Moreover, this has been empirically ascertained by separate estimation of $S_{R}$ for subareas of higher (Kazdag massif) and lower uplift rate. The obtained values respectively amounted to 0.30 and 0.33 , thus being statistically different neither from each other, nor from the regional figure of 0.32 . In brief, the morphological and lithological settings of the region lend themselves ideally to a reliable $R / S_{R}$ analysis, which resulted in an age estimate of $0.8 \mathrm{Ma}$ (late Early Pleistocene) for the last pulse, or acceleration, of uplift within the Plio-Quaternary phase of extension and uplift in NW Turkey.

\subsection{Knickpoint analysis}

The results of the knickpoint propagation modelling are presented in Table 2 and Fig. 3A. The fit is only of moderate quality, probably because of the imbalanced spatial distribution of the data (small travel distances for knickpoints migrating in the small catchments of the Kazdag Mountains versus longer distances for knickpoints in larger catchments in the rest of the Peninsula) and small variations in actual $\mathrm{K}$ values (while $\mathrm{K}$ is considered spatially constant in the modelling), most easily explained by spatial changes in uplift rate and/or lithology. However, the distance residuals (mean residual $=0.2 \mathrm{~km}$, standard deviation $=5.5 \mathrm{~km}$ ) do not show any spatial clustering that would have contradicted the regional character of the tectonic signal at the origin of the erosion wave (Fig. 3A). As for the parameterization of the stream power law, the obtained $\mathrm{K}$ values cannot be directly compared with those of the literature owing to the case-dependent trade-off between $\mathrm{K}$ and $\mathrm{m}$. We thus first scaled all (published and calculated) $K$ values with $\mathrm{m}=0.5$ (and under the assumption of $\mathrm{n}=1$ ) according to the empirical relation $\Delta\left(\log _{10} \mathrm{~K}\right) \approx-8 \Delta \mathrm{m}$, a figure repeatedly appearing in the mapping of model misfit in the $(\mathrm{K}, \mathrm{m})$ space (Beckers et al., submitted for publication; Berlin and Anderson, 2007). Then, as $\mathrm{K}$ is admittedly strongly dependent on, notably, precipitation depth, bedrock erodibility, and uplift rate, we used these factors to separate the published $\mathrm{K}$ values in three groups of distinct erosion efficiency. In the intermediate group, we gathered regions with similar controls 
on $\mathrm{K}$ as those in the Biga Peninsula, namely predominant volcanic and metasedimentary rocks, uplift rate $<0.5 \mathrm{~mm} / \mathrm{yr}$, and annual rainfall between 0.7 and $1.5 \mathrm{~m}$ (Sarıkaya et al., 2008). Regions with harder bedrock (crystalline rocks) or more arid conditions $(\mathrm{P}<0.5 \mathrm{~m}$ ) were assigned to the group of lower erosional efficiency, while regions with either softer bedrock (e.g., mudstones), higher annual rainfall ( $P>2 \mathrm{~m}$ ), or higher uplift rate $(\mathrm{U}>3 \mathrm{~mm} / \mathrm{yr})$ formed the third group, of higher erosional efficiency. Doing so, we reduced the range of plausible scaled $\mathrm{K}$ values in the Biga Peninsula to about one order of magnitude, from $\sim 0.710^{-6}$ to $10^{-5}$.

The knickpoint modelling results show that, in the Biga Peninsula, uplift ages within the $0.5-1.3 \mathrm{Ma}$ range yielded by the $R / S_{R}$ morphometric analysis lead to $\mathrm{m}$ and $\mathrm{K}$ estimates of respectively $0.70-0.72$ and $1.9 \times 10^{-8}-7.5 \times 10^{-8}$. Scaled with $\mathrm{m}=0.5$, these $\mathrm{K}$ values fall in the range $1.1 \times 10^{-6}-3.0 \times 10^{-6}$ and are therefore quite consistent with those published for regions undergoing similar climatic, lithological, and tectonic controls (Fig. 7). By contrast, the scaled $\mathrm{K}$ estimate of $4.6 \times 10^{-7}$ obtained when constraining the uplift age to $3 \mathrm{Ma}$ is inconsistent with the available set of published values, clearly showing that the erosion wave materialized by the studied set of knickpoints cannot correspond to the onset of the Plio-Quaternary uplift phase of the Kazdag, but responded rather to a later signal within this phase. As for the $\mathrm{K}$ estimate $\left(1.5 \times 10^{-5}\right)$ associated with an age constraint of $0.1 \mathrm{Ma}$, it falls outside the range of plausible values but very close to its highest limit under environmental conditions similar to those of the Biga region, suggesting that an uplift age slightly lower than that delivered by the $R / S_{R}$ analysis might also be compatible with the knickpoint data set.

\section{Discussion}

\subsection{Uplift characteristics}

Our morphometric dating of the last uplift event in the Biga Peninsula, and especially in the Kazdag massif, represents an independent age estimate. As a whole, the results of the knickpoint analysis constitute another independent line of argument tending to support the early Middle Pleistocene age of the uplift signal. These estimates need now to be compared with the uplift/incision chronology that may be defined from other geomorphic and geological data.

It is difficult to decide whether this event was a short-lived pulse of accelerated uplift or the onset of a longer-lasting increase in uplift rate. The presence of retreating knickpoints in the drainage system would rather favour the pulse hypothesis. Though somewhat obscured by its drowning below the Gönen reservoir, the knickpoint-

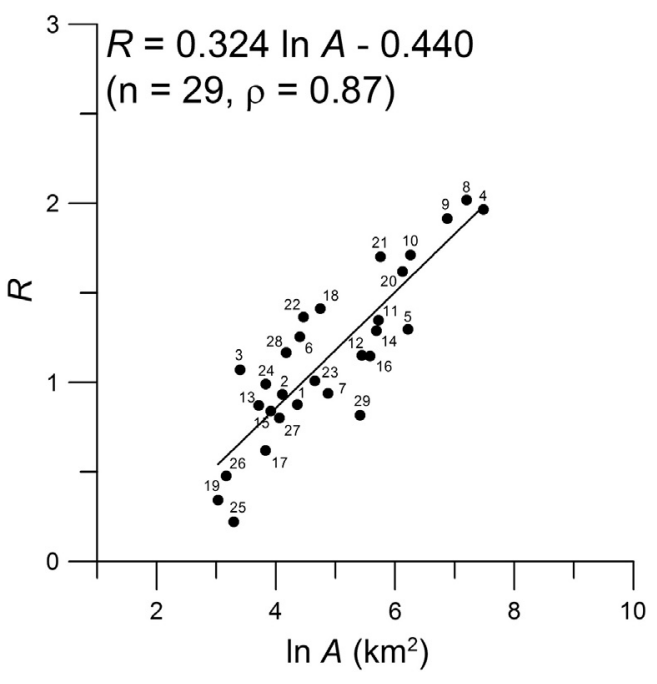

Fig. 6. Regional dependence of the $R$ metric on catchment size $A$ in the Biga Peninsula, NW Turkey.

like discontinuity observed in the present long profile of the Gönen River, one of the major regional rivers, allows estimating the amount of base level drop that caused it to form. Using the 0.75 concavity value calculated for the equilibrium profile upstream of the knickpoint's current position, we reconstructed its pre-incision downstream prolongation (Fig. 8), which passes a good $60 \mathrm{~m}$ above the present profile south of the city of Gönen, where Efe et al. (2011) described upper terrace remnants. We thus tentatively suggest that the prolonged profile might correspond to their highest terrace level, whose relative elevation is of $~ 80 \mathrm{~m}$ about $10 \mathrm{~km}$ south of Gönen, where the knickpoint initially formed at the limit between the Gönen basin to the north and the uplifting massif to the south.

We may also infer approximate incision depths from the observed relative positions of the $H_{n}$ and $H_{r}$ curves with respect to their expected positions at equilibrium for a given basin size. Such data for the largest rivers of the region (Karamenderes, Gönen, Biga) consistently indicate that the amplitude of the erosion wave was in the order of 70-90 m, i.e., a non-negligible fraction of the $\sim 500 \mathrm{~m}$ of Plio-Quaternary uplift in the peninsula. If such an early Middle Pleistocene uplift pulse may be correlated with the tectonic transition described by Schattner (2010) at the same time in eastern Mediterranean, its short duration would imply an uplift rate in
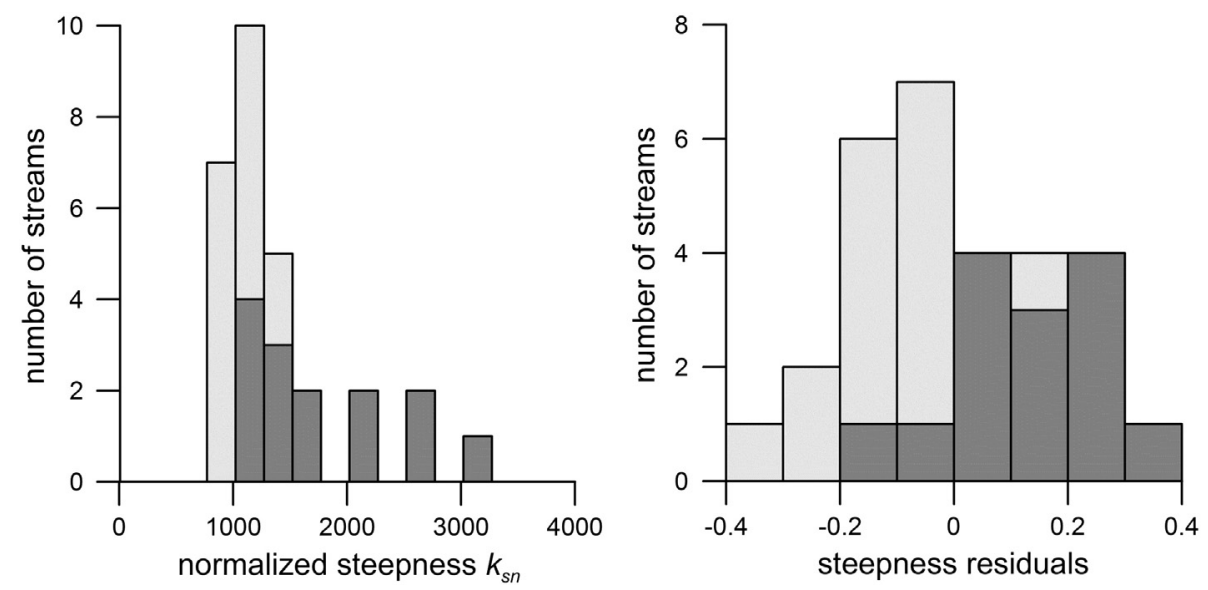

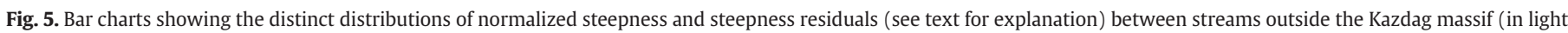
grey) and streams originating in the massif (in dark grey). 
Table 2

Adjustment of the stream power law to the knickpoint data set of the Biga Peninsula under various time constraints (in bold and italics, respectively most probable time and limits of the time range determined from the $R / S_{R}$ analysis).

\begin{tabular}{llll}
\hline Time constraint & Best m & Best K & Misfit $\left(\mathrm{m}^{2}\right)$ \\
\hline $0.1 \mathrm{Ma}$ & 0.74 & $1.85 \times 10^{-7}$ & $4.00 \times 10^{8}$ \\
$0.5 \mathrm{Ma}$ & 0.70 & $7.52 \times 10^{-8}$ & $3.99 \times 10^{8}$ \\
$\mathbf{0 . 8} \mathrm{Ma}$ & $\mathbf{0 . 7 2}$ & $\mathbf{3 . 2 7} \times \mathbf{1 0}^{-\mathbf{8}}$ & $\mathbf{3 . 9 9} \times \mathbf{1 0}^{\mathbf{8}}$ \\
$1.3 \mathrm{Ma}$ & 0.72 & $1.88 \times 10^{-8}$ & $4.00 \times 10^{8}$ \\
$3.0 \mathrm{Ma}$ & 0.73 & $6.65 \times 10^{-9}$ & $4.00 \times 10^{8}$ \\
\hline
\end{tabular}

the order of $0.5-1 \mathrm{~mm} / \mathrm{yr}$, significantly higher than the background rate of $\sim 0.2 \mathrm{~mm} / \mathrm{yr}(\sim 500 \mathrm{~m} / \sim 3 \mathrm{Ma})$.

\subsection{Marine terraces, basin sedimentation and river terraces}

In principle, two main geomorphic markers may be used for comparison purposes, namely marine and river terraces. Considering the distribution of elevated areas in the Biga Peninsula, uplifted marine terraces may be expected to be present especially along the northern coast of the Edremit gulf and in the Çanakkale Strait.

Although marine terraces raised up to $80-100 \mathrm{~m}$ asl by normal fault movements are mentioned along the coast of the Edremit gulf west of Küçükkuyu (Yilmaz and Karacik, 2001), neither a detailed study of their distribution, nor any age indication is available so far. Likewise, the greatest seismic stratigraphic resolution proposed for the sediment pile in the gulf of Edremit does not go beyond separating 4 layers within Neogene deposits overlain by Holocene sediments (Kurtuluş et al., 2009), or an upper 200- to 750-m-thick sequence corresponding to the 'post Lower Pliocene' graben fill (Yilmaz and Karacik, 2001), and is thus of no help for detecting phases of increased activity within the Plio-Quaternary period in this area. However, Işler et al. (2008) interestingly mentioned that Quaternary sedimentation in the Bayramiç depression, northwest of the Kazdag massif, might have come to an end around $1.2 \mathrm{Ma}$, yielding to river incision through the $\sim 150$-m-thick early Pleistocene fill since then. This suggests that, from this time, the depression ceased to behave individually and was incorporated in the regional uplift trend that our $R / S_{R}$ results identify approximately at the same time.

In the north of the peninsula, Yaltırak et al. (2000) noted that remnants of shore deposits belonging to the Middle to Late Pleistocene Marmara Formation (Sakınç and Yaltırak, 1997) are observed as

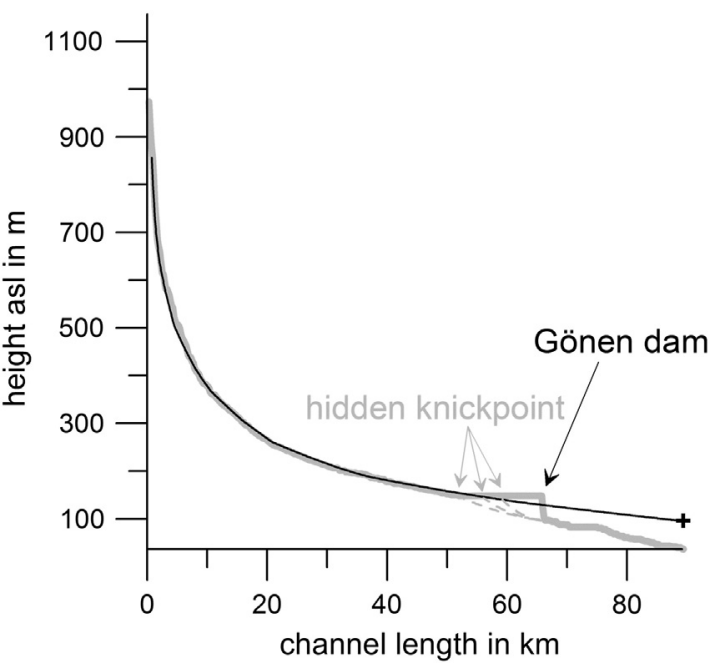

Fig. 8. Longitudinal profile of the Gönen River (thick grey line) upstream of its entrance in the Gönen basin, showing the vertical coincidence between the highest terrace level of Efe et al. (2011) (black cross) and the pre-incision profile of the river (black line). The dashed grey lines underline the uncertainty about the exact location of the knickpoint (currently hidden below the Gönen reservoir) separating the rejuvenated and pre-incision segments of the river profile.

raised marine terraces at various elevations along the Çanakkale Strait. According to dates obtained not only for these onshore deposits but also for sediments that Yaltırak et al. (2000) considered as their offshore counterpart in the eastern Marmara Sea (although Gökaşan et al. (2008) interpreted the same seismic data in a substantially different way), uplift of the Strait's coasts would be going on since at least $600 \mathrm{ky}$. Relying on U/Th age data and comparing the present elevation of these marine terraces with sea level stand in the Marmara Sea during sediment deposition, Yaltırak et al. (2002) provided uplift rates for the Strait area on the order of $0.4 \mathrm{~mm} / \mathrm{yr}$ since $\sim 225 \mathrm{ka}$. However, the Çanakkale basin, in which the marine terraces are found, is morphologically clearly distinct from the uplifted NW part of the Biga Peninsula, also called the BozcaadaBiga ridge by Gökaşan et al. (2011) (Fig. 1B). The Late Miocene to Quaternary clastic sediments of the basin lie unconformably on the pre-Miocene to Miocene basement that constitutes the ridge, evidencing

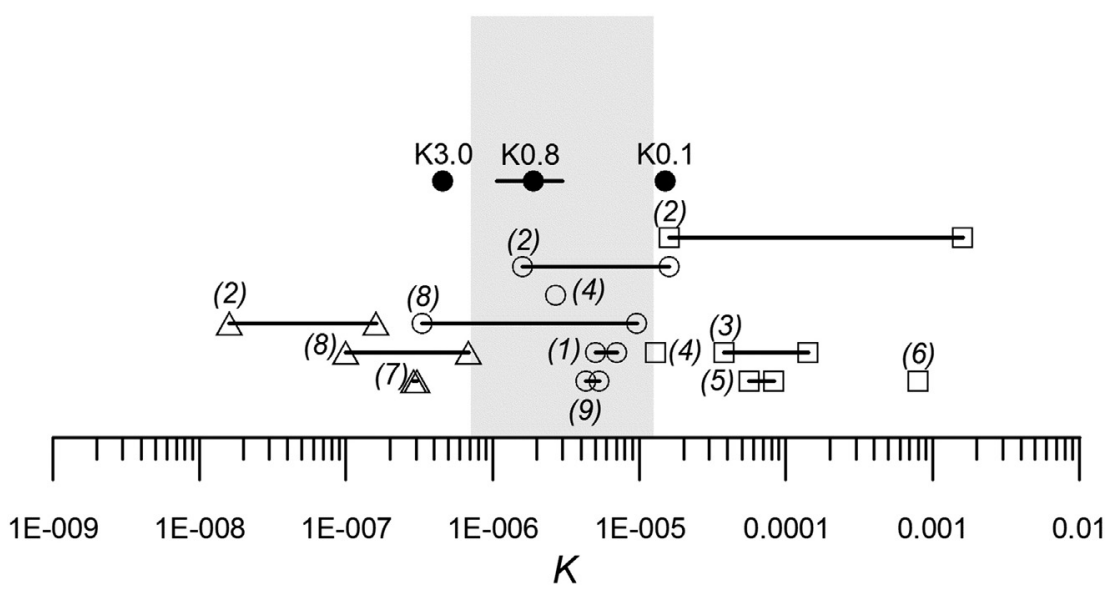

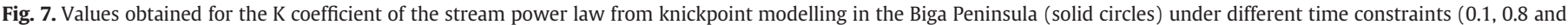

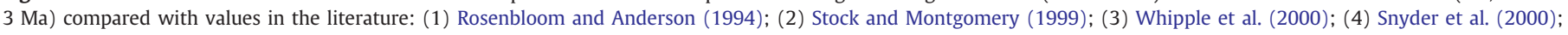

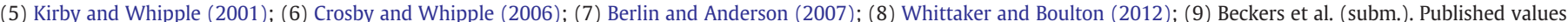

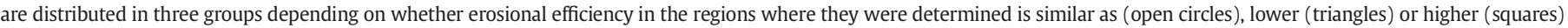

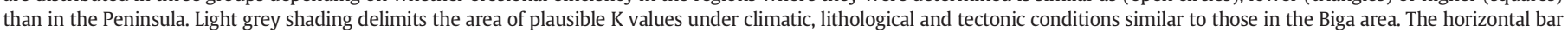
accompanying the $0.8 \mathrm{Ma}$ estimate of $\mathrm{K}$ in the Biga Peninsula shows the range of $\mathrm{K}$ values corresponding to the age range $(0.5-1.3 \mathrm{Ma})$ determined by the $R / S_{R}$ analysis. 
differential vertical movement between basin and ridge during this period (Gökaşan et al., 2011), at least until raised marine terraces indicate recent inclusion of the basin in the uplift area, much in the same way as the Bayramiç depression though with more poorly constrained dating (>600 ka?).

Available data on the river terrace staircase in the valleys of the Biga Peninsula are still fewer and less conclusive. For instance, Efe et al. (2011) mentioned the presence of two levels of 'upper terraces' at 100-130 and 50-70 m asl (which approximately corresponds to 80 and $30 \mathrm{~m}$ above the present floodplain) along the course of the Gönen River at its entrance in the Gönen basin. They claimed, but did not demonstrate, that river incision and terrace formation were due to an acceleration of uplift during the Early and Middle Pleistocene. In addition, Erol (1981, 1982), Efe (1994), Koç (2007) and a few others also provided scattered qualitative information on river terraces in several valleys of the peninsula, which is unfortunately totally useless for our purpose.

In summary, very few data are so far available to trace back the peninsula's Quaternary uplift. There is in particular an urgent need for detailed terrace studies in the Biga Peninsula, including terrace dating. Meanwhile, the usefulness of the quantitative morphometric approach as an exploratory tool in regions devoid of dated geomorphic markers is highlighted. In the absence of dated terraces, the $R / S_{R}$ age of $0.8 \mathrm{Ma}$ for the last uplift event in the region appears fairly consistent with the limited time information provided by geological data, namely the sedimentation/erosion history of the Bayramiç depression and the Çanakkale area, and it will serve guiding further analysis of the geomorphic indicators of uplift.

\subsection{Geodynamic meaning of a Biga Peninsula uplift around $0.8 \mathrm{Ma}$}

Authors dealing with the recent vertical tectonic evolution of the Biga Peninsula generally favour one of two probably superposed influences, namely $\mathrm{N}-\mathrm{S}$ back-arc extension activating a series of $\mathrm{E}-\mathrm{W}$ grabens (up to the Edremit and Bayramiç-Etili grabens to the north) and horsts in the rear of the Hellenic subduction zone, or shear deformation along the northern edge of the west-moving Anatolian microplate, with either transpression or transtension along differently oriented segments of the NAFZ. Extension is assumed to prevail regionally since the Late Miocene, while westward propagation of the North Anatolian Shear Zone in the peninsula occurred during Plio-Quaternary times (Sengör et al., 2005). Even though the deformation has concentrated on the northern branch of the NAFZ probably since $200 \mathrm{ka}$ (Le Pichon et al., 2001), the central and southern branches running across the peninsula are still active, as demonstrated by several earthquakes of $M_{w} \sim 7$ that occurred there during the last 100 years.

In this context, the results of the $R / S_{R}$ morphometric analysis combine well with the observation of Middle Pleistocene basin inversion in the Bayramiç and Çanakkale areas to show that, from 0.8 Ma onwards, the peninsula as a whole underwent uplift. Therefore, whereas transpression along SW-trending segments of the NAFZ branches (Gökaşan et al., 2011; Okay and Satir, 2000) and/or horst development previously caused localized uplift in the Kazdag massif s.s. and the Bozcaada-Biga ridge, an additional, more regional cause of deformation seems to appear at that time. Such a larger-scale trigger might be found in a temporary increase of compressive stresses within the Anatolian plate, whose westward motion is resisted by the GreeceBalkan domain. This resistance induced firstly anticlockwise rotation of western Anatolia toward SW (Sengör and Yilmaz, 1981), probably in the last 2-3 My according to palaeomagnetic data (Piper et al., 2010), and possibly led to extension between a number of blocks behaving as broken slats in the intervening area (Taymaz et al., 1991; Yaltırak et al., 2012). Then, plate convergence caused the Eratosthenes seamount, rising more than $1 \mathrm{~km}$ above the oceanic crust of eastern Mediterranean, to collide with the Cyprus arc in the late Early
Pleistocene, temporarily interrupting subduction and triggering compression of the Anatolian plate (Schattner, 2010). In the frame of this early-to-mid Pleistocene tectonic event, we suggest that rotation of western Anatolia might have been supplemented, around $0.8 \mathrm{Ma}$, by a compressional component focused on the bending tip of the Anatolian plate. Forming the western limb of a major N-S tectonic hinge line that changes the structural grain from NW to SW in the bending area (Yilmaz et al., 2010) and that thus potentially concentrates the deformation, the Biga Peninsula (and probably also the equally uplifted Balikesir Plateau to the east) would have accommodated a main part of this compressive component through increased uplift. Indeed, though this compression episode, documented also in central Anatolia by fault kinematic analyses (Barka et al., 2000; Over et al., 1997), was probably short-lived, the resulting temporary increase in uplift rate was sufficient to induce a wave or river incision that is still propagating within the regional drainage system, as revealed by our $R / S_{R}$ results. One may further hypothesize that the recent transfer and concentration of shearing in the narrower line of the northern branch of the NAFZ, along the northern edge of the peninsula, also responded to these momentarily changed stress conditions. However, the high steepness of the long profiles of streams flowing down the Kazdag massif, which indicates persisting higher uplift rates in this area, and the continued seismotectonic activity of the southern branch of the NAFZ, bear witness to the persistence, after the compressional episode, of a more local transpressive component of uplift.

\section{Conclusions}

Based on the use of classical long profile metrics and the new $R / S_{R}$ global approach of the regional drainage network, the morphometric analysis of the fluvial landscape of the Biga Peninsula, NW Turkey, provided quantitative information on the time of the last tectonic perturbation that caused a regional relative base level lowering large enough to trigger a wave of regressive erosion with measurable morphological effects. Also recorded by migrating knickpoints in a set of river long profiles, this event has been estimated to date back to $\sim 0.8 \mathrm{Ma}$ and seems to be echoed in a change of sense of the vertical motion in several previously subsiding basins. It might correspond to a temporary regional-scale compressional episode caused by the Eratosthenes seamount colliding with the Cyprus arc, and transmitted to the peninsula through the westward push of Anatolia on the Aegean domain. Moreover, the concavity/steepness analysis of river long profiles indicates that current uplift rates remain higher in the Kazdag massif than in the rest of the peninsula, most probably suggesting that transpressive conditions associated with the Plio-Quaternary propagation of the North Anatolian Shear Zone in the peninsula continue to locally produce an additional component of uplift. These findings bring therefore new geomorphic data that helps to address the discussion of the complex geodynamic evolution of the Aegean domain. They also underline the usefulness of the geomorphometric approach, which should systematically belong to the range of techniques applied in the study of tectonically active areas.

\section{Acknowledgements}

We thank Prof. An Yin, Dr Alex Whittaker, and the two anonymous reviewers of a first version of this paper, whose comments stimulated us to clarify important points and provide additional support to our results.

\section{References}

Altunkaynak, Ş., Genç, Ş., 2008. Petrogenesis and time-progressive evolution of the Cenozoic continental volcanism in the Biga Peninsula, NW Anatolia (Turkey) Lithos 102, 316-340. 
Armijo, R., Meyer, B., Hubert, A., Barka, A., 1999. Westward propagation of the North Anatolian fault into the northern Aegean: timing and kinematics. Geology 27, 267-270.

Barka, A., Kadinsky-Cade, K., 1988. Strike-slip fault geometry in Turkey and its influence on earthquake activity. Tectonics 7, 663-684.

Barka, A., Akyuz, S., Cohen, H., Watchorn, F., 2000. Tectonic evolution of the Niksar and Tasova-Erbaa pull-apart basins, North Anatolian Fault Zone: their significance for the motion of the Anatolian block. Tectonophysics 322, 243-264.

Bayer Altin, T., 2012. Neotectonic development of drainage networks studied using geomorphic indices in the Kaz Mountain (Ida), North Aegean region, Turkey. In: Efe, R., Ozturk, M., Ghazanfar, S. (Eds.), Environment and Ecology in the Mediterranean Region. Cambridge Scholars Publ., pp. 283-297.

Beckers, A., Bovy, B., Hallot, E., Demoulin, A., 2013. Factors of knickpoint migration in a drainage network of the moderately uplifted Ardennes Plateau, Western Europe. Geologica Belgica (submitted for publication).

Bell, R., McNeill, L., Bull, J., Henstock, T., Collier, R., Leeder, R., 2009. Fault Architecture, basin structure and evolution of the Gulf of Corinth Rift, central Greece. Basin Research. http://dx.doi.org/10.1111/j.1365-2117.2009.00401.x.

Berlin, M., Anderson, R., 2007. Modeling of knickpoint retreat on the Roan Plateau, western Colorado. Journal of Geophysical Research 112, F03S06. http://dx.doi.org/ 10.1029/2006JF000553.

Bonev, N., Beccaletto, L, 2007. From syn- to post-orogenic Tertiary extension in the north Aegean region: constraints on the kinematics in the eastern Rhodope-Thrace, Bulgaria-Greece and the Biga Peninsula, NW Turkey. In: Taymaz, T., Yilmaz, Y. Dilek, Y. (Eds.), The Geodynamics of the Aegean and Anatolia: Geol. Soc., London, Spec. Publ., 291, pp. 113-142.

Cavazza, W., Okay, A., Zattin, M., 2009. Rapid early-middle Miocene exhumation of the Kazdağ Massif (western Anatolia). International Journal of Earth Sciences 98, 1935-1947.

Chen, Y., Sung, Q., Cheng, K., 2003. Along-strike variations of morphotectonic features in the Western Foothills of Taiwan: tectonic implications based on stream-gradien and hypsometric analysis. Geomorphology 56, 109-137.

Cheng, K., Hung, J., Chang, H., Tsai, H., Sung, Q., 2012. Scale independence of basin hypsometry and steady state topography. Geomorphology 171-172, 1-11.

Çiftçi, N., Bozkurt, E., 2009. Pattern of normal faulting in the Gediz Graben, SW Turkey. Tectonophysics 473, 234-260.

Croissant T., 2012. Application à des paysages synthétiques d'une nouvelle mesure morphométrique permettant de déterminer l'âge d'un soulèvement tectonique. Unpubl. Mém. de Recherche, UJF Grenoble, 24 pp.

Crosby, B., Whipple, K., 2006. Knickpoint initiation and distribution within fluvia networks: 236 waterfalls in the Waipaoa River, North Island, New Zealand. Geomorphology 82, 16-38.

Cucci, L 2004. Raised marine terraces in the Northern Calabrian Arc (Southern Italy): $600 \mathrm{kyr}-$ long geological record of regional uplift. Annals of Geophysics 47, 1391-1406.

Cürebal, I., Erginal, A., 2007. Analysis of geomorphological features of Mihli Creek basin using geomorphic indices. Trakya University Journal of Social Science 19, 126-135.

Demoulin, A., 2011. Basin and river profile morphometry: a new index with a high potential for relative dating of tectonic uplift. Geomorphology 126, 97-107.

Demoulin, A., 2012. Morphometric dating of the fluvial landscape response to a tectonic perturbation. Geophysical Research Letters 39, L15402. http://dx.doi.org/10.1029/ 2012GL052201.

Dilek, Y., 2006. Collision tectonics of the Mediterranean region: causes and consequences. In: Dilek, Y Pavlides, S. (Eds.), Postcollisional Tectonics and Magmatism in the Mediterranean Region and Asia: Geol. Soc. Am. Spec. Pap., 409, pp. 1-13. http://dx.doi.org/10.1130/2006.2409(01).

Efe, R., 1994. Geomorphologial evidence of the Neotectonic movements in Biga Peninsula. Türk Coğ. Derg., 29 209-242.

Efe, R., Soykan, A., Cürebal, I., Sönmez, S., 2011. Reviewing the geomorphologic and neotectonic features of the Gönen Basin (NW of Turkey). Procedia Social and Behavioral Science 19, 716-725.

Erol, O., 1981. Neotectonic and geomorphologic evolution of Turkey. In: Fairbridge, R (Ed.), Neotectonics: Zeitschr f. Geom. Suppl. Bd, 40, pp. 193-211.

Erol, O., 1982. Geomorphologic results of the west Anatolia and its young tectonic. Geol. Congr. of Turkey on West Anatolia young tectonic and its volcanism, pp. 15-21.

Flint, J., 1974. Stream gradient as a function of order, magnitude, and discharge. Water Resources Research 10,969-973.

Floyd, M., Billiris, H., Paradissis, D., Veis, G., Avallone, A., Briole, P., McClusky, S., Nocquet J.M., Palamartchouk, K., Parsons, B., England, P., 2010. A new velocity field for Greece: implications for the kinematics and dynamics of the Aegean. Journal of Geophysical Research 115, B10403. http://dx.doi.org/10.1029/2009JB007040.

Gökaşan, E., Ergin, M., Özyalvaç, M., Sur, H., Tur, H., Görüm, T., Ustaömer, T., Batuk, F. Alp, H., Birkan, H., Türker, A., Gezgin, E., Özturan, M., 2008. Factors controlling the morphological evolution of the Canakkale Strait (Dardanelles, Turkey). GeoMarine Letters 28, 107-129.

Gökaşan, E., Görüm, T., Tur, H., Batuk, F., 2011. Morpho-tectonic evolution of the Çanakkale Basin (NW Anatolia): evidence for a recent tectonic inversion from transpression to transtension. Geo-Marine Letters. http://dx.doi.org/10.1007/ s00367-011-0262-y.

Gürer, Ö., Sangu, E., Özburan, M., 2006. Neotectonics of the SW Marmara region, NW Anatolia, Turkey. Geological Magazine 143, 229-241.

Hack, J., 1973. Stream-profile analysis and stream-gradient index. Journal of Research of the U. S. Geological Survey 1, 421-429.

Isler, E., Aksu, A., Yaltirak, C., Hiscott, R., 2008. Seismic stratigraphy and Quaternary sedimentary history of the northeast Aegean Sea. Marine Geology 254, 1-17.
Jolivet, L., Brun, J.P., 2010. Cenozoic geodynamic evolution of the Aegean. International Journal of Earth Sciences 99, 109-138.

Kirby, E., Whipple, K., 2001. Quantifying differential rock-uplift rates via stream profile analysis. Geology 29, 415-418.

Koc, T., 2007. Geomorphology of north part of Kaz mountain (Ida, Bayramiç-Canakkale). Coğ. Bil. Derg., 5 27-53.

Kürçer, A., Chatzipetros, A., Tutkun, S., Pavlides, S., Ateş, Ö., Valkaniotis, S., 2008. The Yenice-Gönen active fault (NW Turkey): active tectonics and palaeoseismology. Tectonophysics 453, 263-275.

Kurtuluş, C., Doğan, B., Sertçelik, F., Canbay, M., Küçük, H., 2009. Determination of the tectonic evolution of the Edremit Gulf based on seismic reflection studies. Marine Geophysical Research 30, 121-134.

Le Pichon, X., Sengör, A., Demirbağ, E., Rangin, C., Imren, C., Armijo, R., Görür, N., Çăatay, N., Mercier de Lepinay, B., Meyer, B., Saatcilar, R., Tok, B., 2001. The active main Marmara Fault. Earth and Planetary Science Letters 192, 595-616.

Meulenkamp, J., Wortel, W., van Wamel, W., Spakman, W., Hoogerduyn, S., 1988. On the Hellenic subduction zone and geodynamic evolution of Crete since the late Middle Miocene. Tectonophysics 146, 203-215.

Okay, A., Satir, M., 2000. Coeval plutonism and metamorphism in a latest Oligocene metamorphic core complex in northwest Turkey. Geological Magazine 137, 495-516.

Over, S., Bellier, O., Poisson, A., Andrieux, J., 1997. Late Cenozoic stress state changes along the central North Anatolian Fault Zone (Turkey). Annales Tectonicae 11, 75-100.

Peters, G., Van Balen, R., 2007. Tectonic geomorphology of the northern Upper Rhine Graben, Germany. Global and Planetary Change 58, 310-334.

Piper, J., Gürsoy, H., Tatar, O., Beck, M., Rao, A., Koçbulut, F., Mesci, B., 2010. Distributed neotectonic deformation in the Anatolides of Turkey: a paleomagnetic analysis. Tectonophysics 488, 30-49.

Reilinger, R., et al., 2006. GPS constraints on continental deformation in the AfricaArabia-Eurasia continental collision zone and implications for the dynamics of plate interactions. Journal of Geophysical Research 111, B05411. http://dx.doi.org/ 10.1029/2005JB004051.

Rosenbloom, N., Anderson, R., 1994. Hillslope and channel evolution in a marine terraced landscape, Santa Cruz, California. Journal of Geophysical Research 99B, 14,013-14,029.

Sakınc, M., Yaltırak, C., 1997. Güney Trakya sahillerinin denizel Pleyistosen cökelleri ve paleocoğrafyası. Bulletin Mineral Research and Exploration (Turkey) 119, 43-62.

Sarıkaya, M., Zreda, M., Çiner, A., Zweck, C., 2008. Cold and wet Last Glacial Maximum on Mount Sandıras, SW Turkey, inferred from cosmogenic dating and glacier modeling. Quaternary Science Reviews 27, 769-780.

Schattner, U., 2010. What triggered the early-to-mid Pleistocene tectonic transition across the entire eastern Mediterranean? Earth and Planetary Science Letters 289, 539-548.

Schildgen, T., Cosentino, D., Bookhagen, B., Niedermann, S., Yıldırım, C., Echtler, H., Wittmann, H., Strecker, M., 2012. Multi-phased uplift of the southern margin of the Central Anatolian plateau, Turkey: a record of tectonic and upper mantle processes. Earth and Planetary Science Letters 317-318, 85-95.

Sengör, A., Yilmaz, Y., 1981. Tethyan evolution of Turkey: a plate tectonic approach. Tectonophysics 75, 181-241.

Sengör, A., Tüysüz, O., Imren, C., Sakinç, M., Eyidoğan, H., Görür, N., Le Pichon, X. Rangin, C. 2005. The North Anatolian Fault: a new look. Annual Review of Earth and Planetary Sciences 33, 37-112.

Seyitoğlu, G., Scott, B., 1991. Late Cenozoic crustal extension and basin formation in West Turkey. Geological Magazine 128, 155-166.

Seyitoğlu, G., Scott, B., 1996. The cause of N-S extensional tectonics in western Turkey: tectonic escape vs. backarc spreading vs orogenic collapse. Journal of Geodynamics $22,145-153$.

Siyako, M., Bürkan, K., Okay, A., 1989. Biga ve Gelibolu yarımadalarının Tersiyer jeolojisi ve hidrokarbon olanakları. Bulletin of the Turkish Association of Petroleum Geologists 1, 183-199.

Snyder, N., Whipple, K., Tucker, G., Merritts, D., 2000. Landscape response to tectonic forcing: DEM analysis of stream profiles in the Mendocino triple junction region, northern California. Geological Society of America Bulletin 112, 1250-1263.

Stock, J., Montgomery, D., 1999. Geologic constraints on bedrock river incision using the stream power law. Journal of Geophysical Research 104B, 4983-4993.

Süzen, M., Toprak, V., Rojay, B., 2006. High altitude Plio-Quaternary fluvial deposits and their implication on the tilt of a horst, western Anatolia, Turkey. Geomorphology $74,80-99$.

Taymaz, T., Jackson, J., McKenzie, D., 1991. Active tectonics of the north and central Aegean Sea. Geophysical Journal International 106, 433-490.

Taymaz, T., Yilmaz, Y., Dilek, Y., 2007. The geodynamics of the Aegean and Anatolia: introduction. In: Taymaz, T., Yilmaz, Y., Dilek, Y. (Eds.), The Geodynamics of the Aegean and Anatolia: Geol. Soc., London, Spec. Publ., 291, pp. 1-16.

Van der Beek, P., Bishop, P., 2003. Cenozoic river profile development in the Upper Lachlan catchment (SE Australia) as a test of quantitative fluvial incision models. Journal of Geophysical Research 108B, 2309. http://dx.doi.org/10.1029/2002JB002125.

Walcott, R., Summerfield, M., 2008. Scale dependence of hypsometric integrals: an analysis of southeast African basins. Geomorphology 96, 174-186.

Whipple, K., 2001. Fluvial landscape response time: how plausible is steady-state denudation? American Journal of Science 301, 313-325.

Whipple, K., Tucker, G., 1999. Dynamics of the stream power river incision model: implications for height limits of mountain ranges, landscape response timescales and research needs. Journal of Geophysical Research 104/B, 17661-17674.

Whipple, K., Snyder, N., Dollenmayer, K., 2000. Rates and processes of bedrock incision by the Upper Ukak River since the 1912 Novarupta ash flow in the Valley of Ten Thousand Smokes, Alaska. Geology 28, 835-838. 
Whittaker, A., Boulton, S., 2012. Tectonic and climatic controls on knickpoint retreat rates and landscape response times. Journal of Geophysical Research 117, F02024. http://dx.doi.org/10.1029/2011JF002157.

Whittaker, A., Cowie, P., Attal, M., Tucker, G., Roberts, G., 2007. Contrasting transient and steady-state rivers crossing active normal faults: new field observations from the central Apennines, Italy. Basin Research 19, 529-556.

Wobus, C., Whipple, K., Kirby, E., Snyder, N., Johnson, J., Spyropolou, K., Crosby, B. Sheehan, D., 2006. Tectonics from topography: procedures, promise, and pitfalls. In: Willett, S., Hovius, N., Brandon, M., Fisher, D. (Eds.), Tectonics, Climate, and Landscape Evolution: Geol. Soc. Am. Spec. Pap., 398, pp. 55-74. http://dx.doi.org/ $10.1130 / 2006.2398(04)$.

Yaltırak, C., Alpar, B., Sakinç, M., Yüce, H., 2000. Origin of the Strait of Çanakkale (Dardanelles): regional tectonics and the Mediterranean-Marmara incursion. Marine Geology 164, 139-156.
Yaltırak, C., Sakinc, M., Aksu, A., Hiscott, R., Galleb, B., Ulgen, U., 2002. Late Pleistocene uplift history along the southwestern Marmara Sea determined from raised coastal deposits and global sea-level variations. Marine Geology 190, 283-305.

Yaltırak, C., Isler, E., Aksu, A., Hiscott, R., 2012. Evolution of the Bababurnu Basin and shelf of the Biga Peninsula: western extension of the middle strand of the North Anatolian Fault Zone, Northeast Aegean Sea, Turkey. Journal of Asian Earth Sciences 57, 103-119.

Yilmaz, Y., 2008. Main geological problems of Western Anatolia and the significance of the Bodrum magmatic province. IOP Conf. Series: Earth Environm. Sci., 2. http:// dx.doi.org/10.1088/1755-1307/2/1/012007.

Yilmaz, Y., Karacik, Z., 2001. Geology of the northern side of the Gulf of Edremit and its tectonic significance for the development of the Aegean grabens. Geodinamica Acta 14, 31-43.

Yilmaz, Y., Gökaşan, E., Erbay, A., 2010. Morphotectonic development of the Marmara region. Tectonophysics $488,51-70$ 